REVIEW ARTICLE

\title{
The development of Sri Lankan biogeography in the colonial period
}

\author{
Rohan Pethiyagoda ${ }^{1, *}$ and Hiranya Sudasinghe ${ }^{2}$
}

\author{
${ }^{1}$ Ichthyology Section, Australian Museum, 1 College Street, Sydney, NSW 2010, Australia \\ ${ }^{2}$ Evolutionary Ecology \& Systematics Lab, Department of Molecular Biology \& Biotechnology, University of \\ Peradeniya, Peradeniya, Sri Lanka
}

Received: 20/06/2017; Accepted: 25/09/2017

\begin{abstract}
Studies of the patterns and processes of biogeography necessarily contingent on a robust taxonomic foundation which, in turn, depends on a thorough exploration of the biota of the concerned regions. The formal exploration of the flora and fauna of Sri Lanka commenced in the second half of the 17th century, during the Dutch colonial period. The earliest cabinet of Sri Lankan plants was acquired by Paul Hermann between 1672 and 1679. This resulted in three floras of Sri Lanka being published in a span of three decades: Hermann (1717), Johannes Burman (1737) and Carl Linnaeus (1747). The publication of nearcomplete 'floras' of India and Sri Lanka at the end of the 19th century paved the way for Henry Trimen to seek to explain the geographic affinities of the Sri Lankan angiosperms, noting the disjunct distributions of several plant groups between Sri Lanka and southern India on one hand, and Sri Lanka and Indomalaya on the other. This allowed John Christopher Willis to undertake further investigations of the distributions of the Sri Lankan flora, especially within the island. Willis was the first botanist to observe the high incidence of microendemism in the island, leading to his since-discredited theory of Age and Area, which argued that taxa with smaller distributions must be of more recent evolutionary origin.
\end{abstract}

In contrast to the development of the floral inventory centred on the Herbarium in the Royal Botanic Garden, Peradeniya, the faunal inventory lacked an institutional foundation. Most species were described by foreign zoologists, often based on specimens that lacked precise locality data. Zoogeographical studies have thus lagged phytogeographic analyses, and also been bedevilled by taxonomic uncertainties. Nevertheless, in his pioneering global zoogeography, Alfred Russel Wallace (1877) considered Sri Lanka, together with South India, as a distinct sub-region of his Oriental Region, thereby recognizing the distinction of the biota of this sub-region from that of the rest of India. Wallace, however, invoked numerous land-bridges to explain faunal disjunctions. Meanwhile, D.N. Wadia's work on the orogeny of the subcontinent helped explain historical biotic connectivity. His identification of the plains of erosion in Sri Lanka laid the ground for the future biogeographic characterization of the island.

By the time of Independence in the mid-20th century, a stable picture of the external relationships of the island's biota had emerged: close and evidently recent links to the southern Western Ghats of India; older links to Indomalaya, evidently severed by the Gangetic 'Chatterjee Partition' and the subsequent desiccation of much of the Indian peninsula; and a handful of possible 'Gondwanan' links to Madagascar. However, the large number of biotic disjunctions between Sri Lanka and regions further afield remained to be explained. Dispersal appears to be the most likely scenario for most of these. Despite the accumulation of vast amounts of geospatial data by the end of the colonial period, a quantitative characterization of the distribution of the flora yet remains a desideratum. For the distribution of animals within the island, only the most rudimentary information existed at the time of Independence, and accretion to this pool of data has been modest even in the 70 years since.

Keywords: Zoogeography, Phytogeography, Ceylon, British India, Gondwana.

\section{INTRODUCTION}

In this article, we trace the progression of information and ideas that led to our present understanding of Sri Lanka's biogeographic context. This is presented through two interwoven strands. First, because the patterns and processes biogeographers seek to discern and understand depend largely on a sound taxonomic foundation, is the story of how the island's biotic inventory came to be built.

We then survey the work of authors who investigated similarities between the fauna and flora of Sri Lanka and those of India, Southeast Asia and regions further afield in the context of the development of knowledge; and those who studied the distributions of plants and animals within the island.

\section{BUILDING SRI LANKA'S FLORISTIC INVENTORY}

\section{The Portuguese Period}

Although the formal exploration of Sri Lanka's plants began only in the second half of the 17th century, the island's botanical products had by then long been known in the West. Cinnamon (Cinnamomum verum), cardamom (Elettaria cardamomum) and black pepper (Piper nigrum), all of which are native to central and south-western Sri Lanka and the Western Ghats of India, had been widely exported to the Mediterranean region since Greek and Roman times (Vaughan and Geissler, 1997; Shaw, 1972). The opening of a sea route to Europe via the African Cape at the turn of the 16th century saw control of the spice trade wrested from the Moorish traders whose monopoly it had been, and vested in the Portuguese crown. 
The accidental arrival in Colombo in 1505 of Don Lourenço de Almeida, a Portuguese naval captain, quickly developed into that country acquiring, through guile and force, a monopoly not only of Sri Lanka's spice productions but also its gemstones and pearl fishery, which had thriven in the seas off Mannar since pre-Christian times (Pethiyagoda, 2007). Portugal's commercial focus, however, was wholly on the acquisition of produce harvested by natives: there are almost no accounts of attempts to establish spice plantations.

By the second half of the 16th century, however, the Portuguese were taking an increasing interest in the plants associated with the indigenous medical traditions of southern India and Sri Lanka. Among the pioneers who attempted to document the region's medicinal plants was Garcia d'Orta (ca 1501-1568), a physician based in Goa, who appears to have visited the island in 1538. In 1563 his Coloquios ("Coloquies on the simples and drugs of India") became the first work to present an account of the region's medicinal plants to Europe. The book, which lists some 60 plants and animals used in the Ayurvedic and Ezhava medical traditions of southern India, gives also the names by which they were locally known. It is not so much a catalog of plants, however, as a discussion of the "relative merits of entirely different sources of medicobotanical knowledge" (Grove, 1998), with d'Orta arguing that the medical knowledge of native Indians was superior to that derived from the Western traditions. The work was quickly translated into Latin and came to be widely read in Europe.

D’Orta was followed by Christóbal Acosta (ca 15251594), a Spaniard, who drew heavily from Coloquios in writing his (1578) Tractado, which contains descriptions of 69 plants. Importantly, the book contains 46 drawings of Indian plants, many of which occur also in Sri Lanka. It was Coloquios that marked the earliest contribution to Asian phytogeography, by enabling the Dutch physician Jacobus Bontius (Jacob de Bondt, ca 1592-1631) to compare the floras of southwest India and Batavia in his (1642) "De medicina Indorum". Bontius thus "accidentally brought the natural treasures of the western coast of India within the commercial interests of his masters of the Dutch East India Company at Batavia” (Heniger, 1986).

\section{The Dutch Period}

With the defeat of the Portuguese by the Dutch in 1658, control of Sri Lanka's spice trade fell to the Dutch East India Company. In a sharp deviation from the Portuguese indifference to cultivation, in 1669 the Dutch administration decided to begin work on two gardens, one at Jaffna and another at Kalutara, for the cultivation of medicinal plants. The Company then went on, in 1671, to appoint Paul Hermann (1646-1695), a German physician, as chief medical officer to its garrison in Sri Lanka. Importantly, he was directed also to undertake an exploration of the island's medicinal flora. Hermann lived and botanised in Sri Lanka for the next seven years, preserving hundreds of plants he collected in the environs of Colombo (it was unsafe then to venture further inland).

Meanwhile, on 7 October 1665, there arrived in Sri
Lanka from the Company's detachment in Malabar, a young Hollander by the name of Hendrik Adriaan van Rheede tot Drakenstein (1636-1691). Hermann had already met van Rheede during a visit to Cochin in 1674, and on the former's advice, van Rheede commissioned native collectors and artists to prepare drawings of as many Malabar plant species as possible. Hundreds of drawings were sent to Arnold Syen (1640-1678), a professor of medicine and botany at Leiden. Between 1678 and 1693 van Rheede published his Hortus Malabaricus (of which he was, however, not the author), a pioneering flora of the Malabar tract of present-day Kerala. Its 12 volumes contain some 1,600 pages and 790 plates depicting 729 species of plants. These descriptions were to become the basis for dozens of scientific names provided by Carolus Linnaeus in his (1753) Species Plantarum, the first work in which Latin binomial nomenclature came to be consistently applied.

Given the close relationship between the floras of Sri Lanka and south-western India, Hortus Malabaricus became the starting point also for the descriptive treatment of the Sri Lankan flora.

Van Rheede made no secret of the fact that the knowledge and illustrations that embellished Hortus came from members of the Ezhava community, who were by tradition palm-toddy tappers and Ayurvedic physicians. It would certainly have been the case that such ethnobotanical expertise was available also in Sri Lanka. Indeed, Philippus Baldeus, a Calvinist minister who sojourned in Jaffna for seven years from 1658, noted in his 1672 book A True and Exact Description of the Most Celebrated East India Coasts of Malabar and Coromandel; also the Great Island of Ceylon... that "Ceylon is sufficiently provided with medicinal herbs, and they cure all the distempers with green herbs, in the use whereof their physicians are better versed (by experience) than many of our pretending chirurgeons" (Peiris, 1952).

Even as van Rheede was botanising in Malabar, Herman's work was progressing in Sri Lanka. As soon as the first copy of Hortus Malabaricus reached the island's shores, envious comparisons were made between the island's flora and that of Malabar. Ceylon's Governor, Rijkloff van Goens (1619-1682), observed (Heniger, 1986):

[The] doctor and herbalist Hermansz ... has (as reported to us) already described in Ceylon more than 10,000 unusual plants, shrubs and herbs, among them a great many which have never been known to any authors. The island of Ceylon is so blessed a land of all sorts of valuable and splendid medicines as any land on earth can be, all this so plentifully that before long only very few medicaments need be sent from the home country. The book you have sent us, called Hortus Malabaricus, does not contain anything that is unknown and plentifully to be obtained in Ceylon, so that one need not go to Malabar for this at all. Those who know both sustain that the herbs and medicines in Ceylon are as much more potent as Ceylon cinnamon exceeds wild Malabar cinnamon. 
Although van Goens exaggerated the size of Hermann's inventory by an order of magnitude, his was the first observation of the remarkable similarity of the floras of south-western Sri Lanka and south-western India. Botanising in and around Colombo between 1672 and 1679, Hermann accumulated an Herbarium containing some 1,000 species, in addition to copious notes and drawings (Lourteig, 1966; Rauschert, 1970; Rice, 1999), identified and catalogued in their entirety by Trimen (1887). The collection included several species of commercial value introduced from the Americas, such as custard apple, guava, cashew nut and capsicum.

Herman returned to Leiden in 1679 , taking with him from Sri Lanka also a cabinet of botanical specimens preserved in alcohol. Between then and his death in 1695, he wrote an account of his collection of Ceylon plants, later (1717) published by his student, William Sherard (ca 16581728), as Musaeum Zeylanicum, the first formal flora of Sri Lanka. Though not nearly as grand as van Rheede's Hortus (Hermann's Musaeum lacked illustrations), the book provided a treasury of information on Sri Lankan plants, including the Sinhala name of almost every species. The fact that almost all these plants possessed local names is an indication of the advanced state of indigenous taxonomic knowledge in the 17th century.

In addition to the specimens upon which Musaeum was based, Hermann had, while in Sri Lanka, sent "Complete Ceylon herbaria" to Johann Commelin (1629-1692), who was superintendent of the botanic garden in Amsterdam. The Amsterdam garden's Ceylon herbarium was further augmented by a collection made in the island by John Hartog, sent thence by Sherard shortly after Hermann's death. Two separate "Hermann herbaria" from Ceylon thus survived Hermann's death: the one he used for his Musaeum, and the other in the Amsterdam botanic garden.

In 1737, just 20 years after Hermann's own Museum, the Dutch botanist Johannes Burman (1706-1779) published Thesaurus Zeylanicus, in which he presented descriptions, together with 110 drawings, of the Ceylon specimens in the Amsterdam herbarium (Trimen, 1887; also van Ooststroom, 1937 and Rauschert, 1970). The herbarium upon which Hermann's Musaeum had been based had, meanwhile, vanished after his widow auctioned it in 1711 .

In 1744, Carolus Linnaeus (1707-1778), the Swedish naturalist whose Species Plantarum (1753) and Systema Naturae (1758) became the starting point of modern botanical and zoological nomenclature, respectively, received from August Günther, the Danish ApothecaryRoyal, a parcel containing four herbarium volumes together with an album of some 400 drawings. Linnaeus immediately recognised these as the ones on which Hermann's Musaeum had been based.

The rediscovery of Hermann's herbarium offered Linnaeus an opportunity to compile, for the first time, an account of the plants of a tropical island. His Flora Zeylanica was published in 1747 and, together with Musaeum Zeylanicum and Thesaurus Zeylanicus ensured that the Sri Lankan flora was well represented in the founder- work of systematic botany, the 1753 edition of Linnaeus's Species Plantarum. In Flora Zeylanica Linnaeus assigned 429 plant species to genera; to a further 228 he was unable to make generic allocations for want of specimens. In all, 657 species were described in Flora Zeylanica, based on Hermann's material. The book was, however, illustrated with just four plates.

When Species Plantarum came to be written, Linnaeus based the names of most of the Sri Lankan plants on the accounts in Flora Zeylanica. He used Hermann's herbarium also to connect Burman's and his own work with Hortus Malabaricus, formally demonstrating the validity of van Goens' claim of a largely shared flora between Malabar and Sri Lanka. In 1748 he published the second edition of Flora Zeylanica, including an appendix edited by Carl Magnus Dassaw (1719-1751), containing 43 new genera of Sri Lankan plants. These were later incorporated into the fifth edition of Genera Plantarum (1754).

The herbarium upon which Hermann's Museum was based is now in The Natural History Museum in London, while that upon which Burman's Thesaurus was based remains in the Naturalis Biodiversity Center - Herbarium Division, at Leiden.

The remainder of the Dutch colonial period in Sri Lanka saw little of note by way of botanical exploration save for the visit in 1777-78 of Carl Peter Thunberg (17431828), who collected extensively during his relatively short stay. Although the Dutch had developed botanic gardens in Colombo and Kalutara, almost nothing is known about them.

\section{The British Period}

The demise of Dutch power in Sri Lanka began with the capture of Trincomalee by the British East India Company in 1796 and ended with the secession of the entire island to the British under the Treaty of Amiens in 1802. By 1810 Joseph Banks had drawn up a plan to establish a botanic garden in the island on the lines of the Royal Botanic Garden at Kew. After the failure of the Dutch gardens in Colombo and Kalutara, a Royal Botanic Garden was finally established in Peradeniya in 1821 under the superintendence of Alexander Moon (?-1825). Moon had begun botanising immediately on his arrival in the island in 1817 , and within two years was able to ship quantities of specimens, including the seeds of 373 plant species, back to the British Museum.

In 1824 Moon published his Catalogue of the indigenous and exotic plants growing in Ceylon, which listed 1,127 species, 366 of them under cultivation in Peradeniya. A further 761 species were catalogued from wild-collected specimens, 164 of these considered as new to science. Sadly, Moon's collection was lost when the gardens went into a decline following his death in 1825, to be revived again only with the appointment of George Gardner (1812-1849) as superintendent in 1844. Gardner immediately commenced work on an illustrated book on the flora of Ceylon; and became the first scientist to protest the extensive clearance of the island's forests by British 
planters. "Botanists of future times will look in vain for many of the species which their predecessors had recorded in the annals of science as natives of the Island", he lamented in the Gardens' annual report of 1844.

Gardner's death in 1849 saw the Peradeniya gardens placed the same year in the care of George Henry Kendrick Thwaites (1812-1882). It was to Thwaites, then, that the task of publishing the first systematic catalogue of the flora of Ceylon fell. This he did between 1858 and 1864 in the form of his Enumeratio plantarum Zeylaniae, in which all the plants then known from Sri Lanka were listed and briefly described. This was one of the earliest comprehensive inventories of a tropical flora, earning its author much fame. Thwaites continued to build the collection of the Peradeniya herbarium until his retirement in 1880, when Henry Trimen (1843-1896) succeeded him as director.

Trimen was among the first botanists to seek to explain the geographic affinities of the Sri Lankan angiosperms (Trimen, 1885), noting the disjunct distributions of several plant groups between Sri Lanka and southern India on the one hand, and Sri Lanka and Indomalaya on the other. His 1885 "Remarks on the composition, geographical affinities, and origin of the Ceylon flora" would thus become the island's first biogeographical work. Equally valuably, his (1893-1900) A hand-book to the flora of Ceylon provided not only a description of every flowering-plant species then known from the island but also, for the first time, contained information on the distribution of every species. Importantly, all his distribution information could be verified from the specimens he preserved in the Peradeniya herbarium. By the time of Trimen's death in 1896 the inventory of flowering plants was largely complete, although a trickle of new-species descriptions continues to this day.

\section{BUILDING THE FAUNAL INVENTORY}

\section{The Dutch Period}

There having been no noteworthy exploration of Sri Lanka's fauna in the Portuguese period, even the Dutch period saw only two important collections that had scientific consequences. The earlier of these is a cabinet of reptile and mammal specimens accumulated in Amsterdam by Albertus Seba (1665-1736), whose Locupletissimi rerum naturalium thesauri accurata descriptio ("An accurate description of the very rich thesaurus of the principal and rarest natural objects') contained 446 coloured plates that included several specimens from Sri Lanka. Many of these species came formally to be named in Linnaeus's (1758) Systema Naturae.

The second was a large collection of animal drawings accumulated by Joan Gideon Loten (1710-1789), from 1752-57 governor of Dutch Ceylon. Loten commissioned Pieter Cornelis De Bevere (1722- ca 1780), a surveyor and competent artist, to illustrate his collection of mainly bird and mammal specimens. The species illustrated in these drawings, now in The Natural History Museum, London, came to be named in later works, notably the 12th (Linnaeus, 1766) and 13th (Gmelin, 1748-1804) editions of Systema Naturae and the various works of Thomas Pennant (1726-1798) (Pennant, 1777, 1781a,b). Loten's drawings provide for zoology a foundation comparable to that provided botany by Hermann.

\section{The British Period}

While the botanical exploration of Sri Lanka was formalized by the appointment of the first superintendent of botanic gardens in 1812, zoology languished without an institution until the opening of the Colombo Museum in 1877. Only a handful of naturalists living in Sri Lanka made substantial contributions to the national faunal inventory in the 19th century, among them Edward Frederic Kelaart (18191860), a medical doctor, whose (1852) Prodromus faunce Zeylanica represents the first attempt by a naturalist to review the island's fauna. In all, Kelaart described 35 new mammalian taxa in addition to three new species of birds, four anurans, 12 snakes, 16 turbellarians and 22 actiniarians in addition to dozens of other discoveries he referred to colleagues overseas.

Edgar Leopold Layard (1824-1900), an official in the colonial administration, was a keen naturalist and avid collector for scientists overseas, importantly Edward Blyth (1810-1873) in Calcutta. During his time in Sri Lanka he succeeded in adding no less than 136 birds to the island's ornithological inventory. He was also a keen collector of smaller animals including worms and insects, and some 20 species of land snails he dispatched to malacologists in England came to be named for him.

Even the opening of the Colombo Museum in 1877 failed to inspire institutional interest in naturalhistory exploration. Modeled on the British Museum and notwithstanding its grand colonial façade, it failed to deliver the hoped-for Zoological Survey of Ceylon. Natural-history studies, however, briefly gained traction with the appointment in 1900 of William Abbott Herdman (1858-1924) to undertake an extensive biological survey of the Gulf of Mannar, with a view to assuring the sustainability of the pearl-oyster fishery. Herdman spent three months in Sri Lanka in 1901, collecting specimens. The results of these studies were presented in his Report to the Government of Ceylon on pearl Oyster Fisheries of the Gulf of Manaar (1903-05). The five volumes and 1,500 pages of this massive work arguably constitute the greatest single natural-history study ever undertaken in the country: in all, 2,615 marine species were identified, including 575 new species and 65 new genera. Two members of Herdman's team would later become directors of the Colombo Museum, from then on skewing the museum's priorities towards marine (and aquatic) biology.

The accession of Paulus Edward Deraniyagala Peiris (1900-73) to the Museum's directorship in 1939 (he had acted in that position since 1937) did little to change that tradition. Easily the most versatile and prolific zoologist Sri Lanka has produced, his publications, spanning the period 1929-63, number some 379 books and papers, including 47 on ichthyology, 75 on herpetology, 15 on ornithology, 45 on mammalogy, and 120 on palaeontology and prehistory. Unfortunately, the Museum's institutional interest in 
biodiversity exploration, always tenuous at best, also ended with the Deraniyagala's directorship (he was a loner and failed to foster an academic lineage) and the field returned once more to amateurs and academics to whom naturalhistory study was no more than a secondary interest.

Despite a number of amateurs making important contributions to knowledge of a diversity of taxa in the course of the 20th century, the lack of institutional focus resulted in such efforts usually not being sustained. In most cases, species were described by overseas specialists from specimens lacking precise locality data. Zoogeographical studies have, as a result, lagged behind phytogeographic analyses and been handicapped also by taxonomic uncertainties. For example, the distribution of the agamid lizard genus Cophotis was considered to be disjunct, with populations known only from the highlands of Sri Lanka and Sumatra, leading to hypotheses of ancient terrestrial connections (Manamendra-Arachchi and Liyanage, 1994). Later taxonomic studies (Manthey and Grossmann, 1997), however, showed the two populations to belong to distinct genera. Similarly, the rhacophorid frog genus Theloderma was considered to be disjunct between Sri Lanka and Southeast Asia (Dutta and Manamendra-Arachchi, 1996) until the Sri Lankan population was shown to belong to the genus Philautus (now Pseudophilautus): ManamendraArachchi and Pethiyagoda, 2005. Although such cases of convergence are easily resolved using molecular methods, the vast majority of Sri Lankan vertebrates remains to be studied by such means.

\section{IDENTIFICATION OF BIOGEOGRAPHIC PATTERNS}

\section{Henry Trimen}

It was Henry Trimen who first investigated associations between the distribution of plant species and the island's topography and climate. Trimen (1886), for example, observed that the flora of the region now referred to as the wet zone (rainfall $>2000 \mathrm{~mm} / \mathrm{y}$ ) differs from that of the dry zone (rainfall $<2000 \mathrm{~mm} / \mathrm{y}$ ) not so much because the latter receives less precipitation but because "the distribution [his emphasis] of rain through the year has so great an influence on fertility". Of the wet zone, he observed, "and in this favoured part there are rarely any long periods without rain. A month's or six weeks' drought in February, March, or April, is the utmost experienced, and this is rarely absolute; during the rest of the year there are frequent showers in nearly every week."

The publication of Trimen's (1893-1900) Handbook to the flora of Ceylon provided opportunities for the first time to investigate the geographical distribution of the island's flowering plants and their global relationships. Trimen (1885) himself made a first attempt at this, remarking on the curious distributions of 108 Sri Lankan species in 86 genera that showed greater affinities to the floras of Southeast Asia, Madagascar, Mauritius and the Mascarene Islands, than to those in neighbouring India. Of the 2,729 species of native flowering plants then recognized from Sri Lanka, he observed that as many as 19 genera and 800 species were endemic. Given that continental drift was then unknown, as were also Earth's climatic history and terrestrial connections during glacial sea-level low-stands, Trimen was at a loss to explain the observed disjunctions except by postulating ancient land bridges (which had been posited also by Edward Forbes in 1846 and, more relevantly to the Gondwanan context, by William Blanford in 1876), for which there was, of course, no evidence at the time.

Following on this, Trimen (1886) remarked so presciently also on the distribution of endemic species within the island that we quote him extensively:

And this leads me to mention one of the most remarkable features of the Ceylon flora, viz., the very large number of species which are peculiar to the island, or, as botanists call it, endemic. About 800 species (nearly 30 per cent.) of the whole number found here are, so far as is known, found nowhere else in the world... the most distinct and well marked of these endemic plants are almost entirely concentrated in this south-west region, which is thus seen to be as peculiar in its flora as in its climatic character. The tree vegetation of the forests above mentioned [viz., Sinharaja, Hiniduma, Neluwa] is almost wholly composed of endemic species, and not a few endemic genera. And it is another significant and remarkable fact, with regard to these, that their affinities and near alliances are with the plants of the Malay Islands and peninsula far more than with the flora of southern India...

He then went on to examine the affinities of Sri Lanka's montane flora:

In distinction from the low-country vegetation, this hill-flora shows no special affinity with Malaya, while it is really very closely allied to that of the Nilgiri Mountains of S. India... Less than 400 miles separates the summits of Pidurutalagala, the highest mountain in Ceylon, and Dodabetta in the Nilgiris (and there are half-way houses in the Pulnis and Anamalais). Yet the curious fact presents itself that more than half the species in the Ceylon hills are not found in the Nilgiris or other hills of the Indian peninsula, but are endemic there, and probably an even larger proportion of Nilgiri species do not extend to Ceylon. The number common to both ranges is only about 200 . Yet very nearly all belong to the same genera, which are almost identical for both regions. It is thus possible to make the contradictory assertions that the floras are very similar and very different... Of the genus Strobilanthes... the Ceylon hills possess twenty-two peculiar species, and the Nilgiris \&c., about twenty nine, whilst only two are found in both regions; of the mountain species of Impatiens, there are two common to both ranges, while Ceylon has ten others endemic... If we suppose a common origin for both these hill-floras in the past, or derive the one from the other, the differences now seen in the two districts indicate a sufficient lapse of time since their separation to allow of the evolution under different surroundings 
of new forms of the rank of species, but not of the superior rank of genera.

Finally, of the flora of the northern dry zone he observed:

The plants of all this dry district of Ceylon are essentially those of the Carnatic and Coromandel coast of the opposite Indian continent. Nearly all of the species are identical, and there is a much greater similarity between the two countries than between the two climatic districts of Ceylon itself. So far as the flora is concerned, one would think the separation of Ceylon from the mainland (now parted by the very shallow Palk's Strait) to be geologically recent; even the few endemic species in this part of Ceylon are all closely related to the continental ones, and clearly derivable from them or from common ancestors. And the Malayan element, so prevalent in the low country of South-west Ceylon, is here conspicuously absent.

\section{J.C. WILLIS'S THEORY OF AGE AND AREA}

The availability of a georeferenced taxonomic 'database' by way of Trimen's Hand-book allowed his successor, John Christopher Willis (1868-1958) to undertake further investigations of the distribution of the Ceylon flora. Adept at handling 'big data' in the age before electronic computers (see Pethiyagoda, 2007: 86), Willis soon set to work on analyzing the Ceylon flora and was the first botanist to observe the high incidence of microendemism in the island (Willis, 1915; see also Figure. 1 and Ashton and Gunatilleke, 1987: 275-277).

Willis was fascinated by endemism and especially the remarkable incidence of the 'micro-endemics' restricted to a single site such as a mountaintop (see Willis, 1906 for Ritigala; Willis, 1908 for hilltop floras generally; and Willis, 1911 for Namunukula). Were these relicts of species that had previously enjoyed wider distributions, he wondered, or had they evolved autochthonously, in situ?

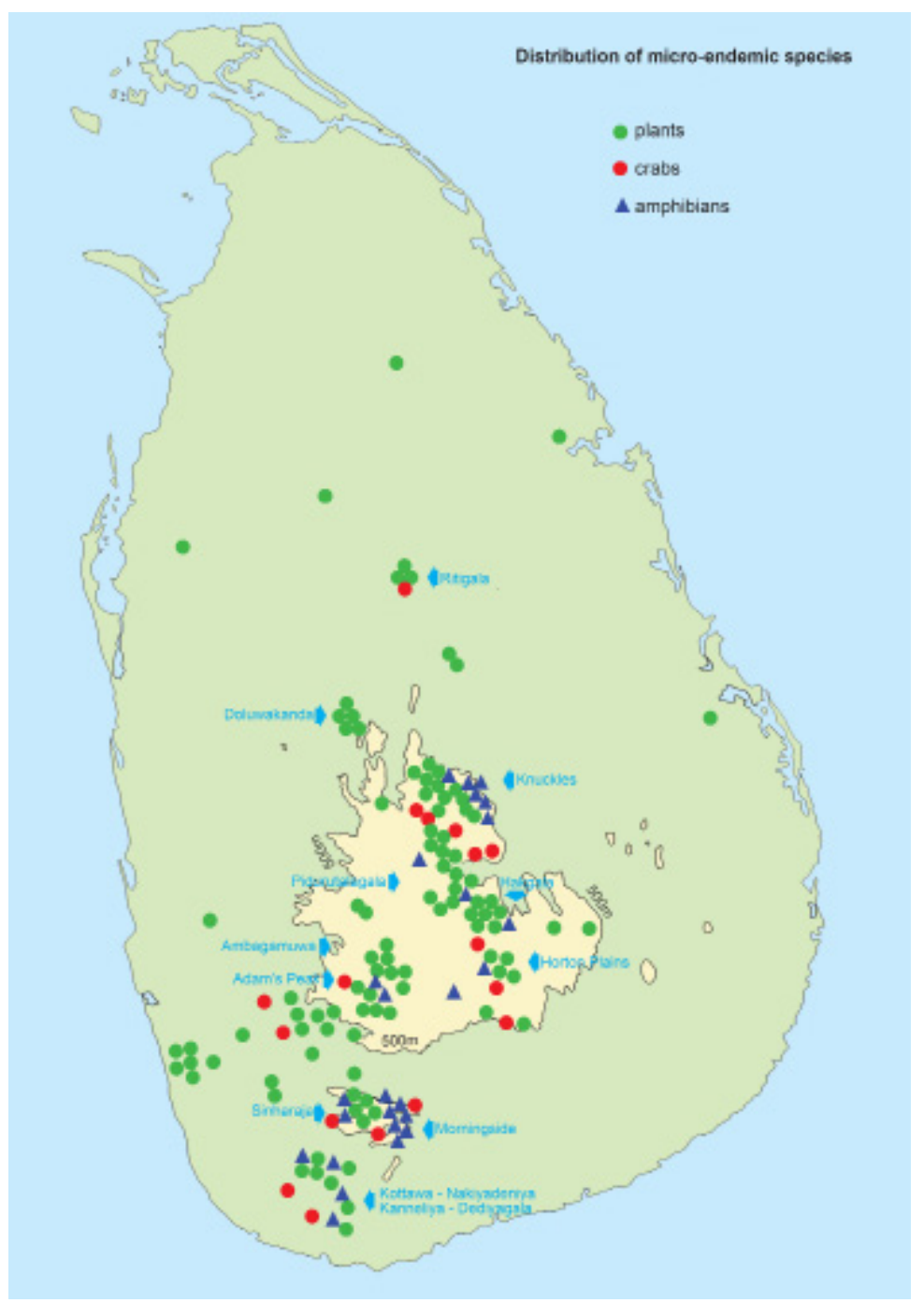

Figure 1: The distribution of micro-endemic vascular plants, amphibians and freshwater crabs in Sri Lanka. Data for plants from Dassananayke and Fosberg (1980-2006) and for amphibians and freshwater crabs from the respective collections in the National Museum of Sri Lanka. 
He rejected the possibility that the ranges of such species might have been restricted by edaphic specialization, or by climate, rainfall, or an inherent inability to disperse. Noting that many micro-endemic species occur in syntopic communities that include non-endemic congeners, he concluded that the former were incipient species that had evolved recently, leading him to conclude that widespread species (and by extension, taxa) were evolutionarily older than ones with more restricted ranges ${ }^{1}$.

Willis hinted at this conclusion in a 1907 paper in the Annals of the Royal Botanic Gardens, Peradeniya and might have let the matter rest had not Sinnott and Bailey (1914), in an early study of plant phylogeny, suggested that herbaceous plants were of more recent origin than woody ones. In a paper read to the Royal Society on 10 December, 1914 , they observed that "There is a great preponderance of herbs in temperate regions and of woody plants in the tropics." They concluded from this observation that "herbaceous vegetation, most richly developed in the great land-mass of the north temperate zone, has spread thence over most of the globe", going on to add, "The endemic plants in a flora are usually to be regarded as its most ancient element... endemic trees or shrubs are almost always very ancient."

Willis (1915) proposed his theory, which soon came to be known as the Theory of Age and Area, not as a direct rebuttal of Sinnott and Bailey's (1914) hypothesis but as an original thesis based on his own analysis of Trimen's plantdistribution data. In his Hand-book, Trimen had mentioned not only which species were endemic to Ceylon, but also provided an index of rarity, on a scale of 1-6. Willis was quick to observe in these data that "The rarest plants in Ceylon are the local endemics, the next most rare those also common to Peninsular India, and the commonest those of wider distribution... From these interesting figures", he continued,

one may conclude that the local endemic species have not been developed in any kind of advantageous response to local conditions. They are much rarer than those species which are also common to Peninsular India, and these again than those of wider distribution...

The second conclusion drawn is that on the average, the commonness of a species depends upon its age from the time of its arrival in, or evolution in, the country. The commonness of any individual species

\footnotetext{
1 Darwin, in his (1861) Origin of Species, had arrived at exactly the opposite conclusion: "as the favoured forms increase in number, so, generally, will the less favoured decrease and become rare. Rarity, as geology tells us, is the precursor to extinction. We can see that any form which is represented by few individuals will run a good chance of utter extinction, during great fluctuations in the nature of the seasons, or from a temporary increase in the number of its enemies. But we may go further than this; for, as new forms are produced, unless we admit that specific forms can go on indefinitely increasing in number, many old forms must become ex-tinct... I think it inevitably follows, that as new species in the course of time are formed through natural selection, others will become rarer and rarer, and finally extinct."
}

will, of course, also depend upon its degree of adaptation to local conditions, and upon many things that can only be regarded as chance, such as the sudden appearance of new factors, like diseases, etc., in the problem. In other words, on the average, species are developed quite indifferently to local conditions, though it is possible that they may be developed because of these conditions.

With this argument, Willis was seduced into the theory of Age and Area: that wide-ranging species are more ancient than narrow-ranging ones. The theory, while accepting the process of evolution, rejected Darwin's proposition that the primary mechanism involved in speciation was natural selection. The accumulation of infinitesimally small variations to create distinctive 'Linnean' species, argued Willis, would take much longer than geological time allowed (Willis, 1907). "Nearly seventy years ago," he wrote, "Lyell [1853] said, 'Might not the births of new species, like the deaths of old ones, be sudden?' and it appears to me... one can hardly arrive at any other conclusion" (Willis, 1922). Willis did not restrict the single-step origin of new species: he claimed that "a single mutation, usually very divergent from the parent form, may give rise, at one step (not gradually as under Darwinism) to a new form, of family, generic, specific or varietal rank" (Willis, 1949). Willis (1942) had given this process the name 'kaleidoscopic mutation', an allusion signifying that with each turn of the spindle, a set of dramatically different shapes appears in the kaleidoscope, based, however, on a combination of standard templates.

An early supporter of the Age and Area theory was the Dutch botanist Hugo Marie de Vries (1848-1935) who, though noted for rediscovering (together with Carl Correns and Erich von Tschermak) Mendel's laws of heredity in 1900, challenged the gradual evolution of species posited by the Darwinian model. Instead, he proposed a Mutation Theory that held that new species arise through single mutations. De Vries (1916), having tested Willis's arithmetic, concluded,

It is obvious that some general law mustbeunderlying these phenomena... If the endemic species had originated by natural selection of infinitesimal steps, and in response to the local conditions, which are obviously the only conditions that matter when the species first appears, they must have been, from this very origin, better adapted to these conditions than their parent species. According to the theory of natural selection it would follow that they must surpass their forerunners in the struggle for life and soon spread to a higher degree of commonness. But... the reverse is true.

Opposition to Willis, however, was quick to galvanize, principally in the form of Henry Nicholas Ridley (1855-1956) who, in a devastating critique in Annals of Botany (1916), systematically demolished Willis's arguments. Given that Willis's original (1915) paper was based largely on the data in Trimen's Handbook, Ridley questioned, for example, Trimen's 'degrees 
of rarity', correctly pointing out that because Trimen's sampling was biased towards the favourite locations of his collectors, conclusions on abundance and distribution would necessarily be subject to sampling bias.

Willis, however, tenaciously clung to his thesis, digging himself deeper into the mire, rebutting his detractors' arguments by surrounding his hypothetical assertions with special conditions that made them impossible to falsify. In all, between 1915 and his death in 1958, he published some 18 papers and three books substantially on Age and Area.

Although kaleidoscopic mutation has, of course, been universally rejected, the determinants of rarity and the relationship between the extent of geographic range and evolutionary age continue to be important fields of study. Even some of its severest critics grudgingly admitted that Age and Area held considerable intuitive appeal: its conclusions appeared almost as obvious and seductive as they were untrue.

Willis's theory is likely to be remembered, however, largely for the debate it caused and the research it precipitated: almost a hundred papers addressing the issue have been published since 1915 and the widespread use of the label 'Age and Area' in the ecological literature shows that it is an idea that lives on, though of course, in a different context.

\section{INTERNAL PHYTOGEOGRAPHY}

Trimen (1885) and Willis (1915) were the earliest workers to recognize the uneven distribution of species in Sri Lanka and seek correlations that explained these. By and large, these authors considered the spatial and temporal distribution of rainfall, together with elevation, to be the primary determinants of plant distributions. Appreciation of edaphic factors and the concept of plant communities, on which Darwin (1861) placed considerable emphasis, were largely neglected.

Even by Trimen's time, however, the deforestation of the wet zone had been so extensive that he recognized the problem of understanding, for example, whether an apparent micro-endemic species had a circumscribed range because it was biologically restricted to a single site, or because its former range had been decimated. "It is chiefly to this low, moist district that they [the "real flora of the country"] are so frequent", he (1886) wrote of the wet-zone lowlands,

"No doubt the whole of this part of Ceylon was once covered with heavy forest; but most of this has now disappeared, and the country is thickly inhabited. The lower lands are mostly devoted to paddy (i.e., rice) cultivation, and the more elevated parts between are occupied by villages... A few portions of original forest still remain in the tracts of country between Ratnapura and Galle, of which that known as the Singhe-Rajah is the most extensive. Here the true native flora of Ceylon can still be seen unaltered, and is of remarkable interest, as will immediately be shown. The agent of destruction of the forests here has been the indolent and improvident practice of native cultivation known as "chena", a practice which has prevailed and been continued from a remote antiquity, and by which, for the sake of a single crop of some miserable grain such as Kurakkan (Eleusine coracana), the forest growth of centuries is sacrificed.

"Native vegetation has also been curiously preserved in a few places which "chena" cultivation has been unable to reach, namely, on the precipitous summits of certain of the small isolated gneiss, rocks, or hills scattered over the south part of the district, such as Hiniduma (or Haycock) and Nillowe Hills. The space on the tops of these rocks is very small and steep, but here, crowded together, are a number of remarkable species mostly peculiar to Ceylon, and in several cases now entirely restricted to the few square yards in question on those isolated spots."

As pointed out by Ashton and Gunatilleke (1987), however, the peopling of the island's south-western wetzone lowlands and the consequent devastation their forests occurred relatively recently, following the retreat of the royal court southwards to Dambadeniya in the thirteenth century. Several authors have nevertheless proposed floristically characteristic forest types for Sri Lanka, identifying distinct floristic provinces (e.g., de Rosayro, 1950; Koelmeyer, 1957; Gaussen et al., 1966; Ashton and Gunatilleke, 1987; Greller and Balasubramaniam, 1993). While varying in detail, the broad floristic provinces they propose are largely consistent with the 15 provinces identified by Ashton and Gunatilleke (1987; see Figure. 2 ), which have been followed by almost all subsequent authors.

Perhaps most notably, Ashton and Gunatilleke (1987) identified several areas of exceptionally high endemism, most importantly the ca $10 \mathrm{~km}$ wide horseshoe-shaped band of foothills that skirt Adams Peak, from Maskeliya in the northwest, south through lowland Ambagamuwa and then eastwards again, through Kuruwita and thence almost to Belihul Oya. "The strip as a whole, and the western half in particular," they noted, "is the wettest and least seasonal part of the lowlands."

The second area of high endemism recognized by Ashton and Gunatilleke (1987) extends from the southern block of hills immediately east of Kalutara, running in an arc parallel to the coast, about $30 \mathrm{~km}$ inland of it, ending just inland of Hulandawa. "This block", they observed, "is without doubt floristically the richest area of Ceylon, and indeed of all South Asia."

Despite a wealth of georeferenced data being available, both from the records of the National Herbarium and the National Conservation Review (Green, 1995), the proposed floristic zones remain to be tested objectively through geospatial analysis. Nevertheless, the 15 floristic provinces recognized as Ashton and Gunatilleke (1987) possess intuitive appeal, and the broad vegetational transition they observed from lowland to hill forest at an elevation of around $1000 \mathrm{~m}$, and from hill to submontane forest at ca $1500 \mathrm{~m}$, have found wide utility (e.g. Wikramanayake, 2002; Gunatilleke et al., 2008). 


\section{EXTERNAL PHYTOGEOGRAPHIC RELATIONSHIPS}

"When we attempt to compare Ceylon with other tropical regions," noted Trimen (1885), "the difficulty meets us that there is scarcely any definite area of which the flora has yet been so thoroughly worked out." While he was right, he omitted to mention (because it not doubt was common knowledge at the time) Joseph Dalton Hooker's (1872-97) encyclopedic Flora of British India, work on which was by then almost complete. Trimen (1885) was thus able to compare the Ceylon and Indian floras, discovering in the process that about a hundred genera of spermatophytes occurring in Ceylon were absent from India; 56 nonendemic genera were absent from India but contained only endemic species in Ceylon; and a further 31 genera were absent from India but contained non-endemic species in Ceylon.

While many of these disjunct taxa have since been discovered in India or shown to be victims of taxonomic uncertainty, some 35 genera remain that occur in Sri Lanka (Table 1) but are absent from the peninsula of India, recurring, however, in the Malay peninsula, Sunda islands or further afield. Indeed, such a distribution is shown even

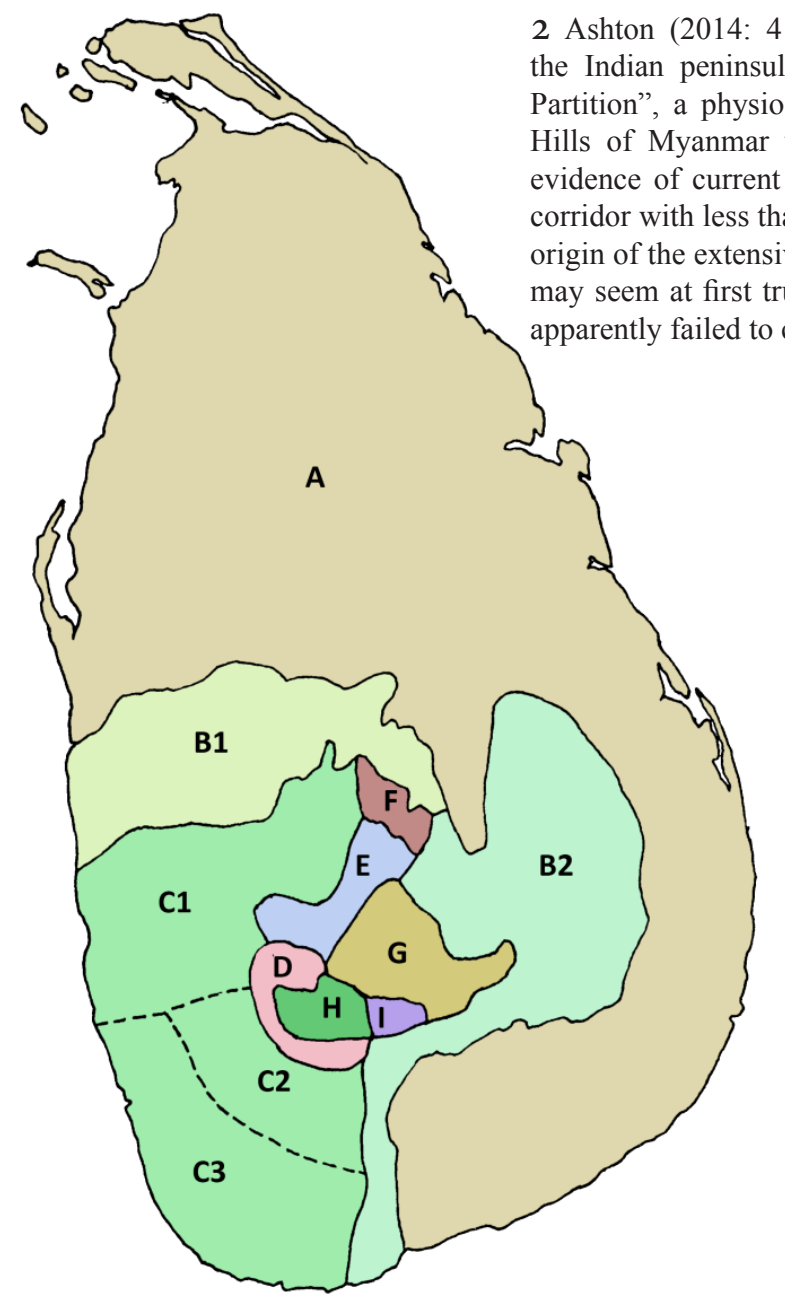

Figure 2: Floristic zones of Sri Lanka; adapted from Ashton et al., (1997). A: Dry zone; B1: Northern Intermediate lowlands; B2: Eastern Intermediate lowlands; C1: Northern Wet lowlands; C2: South of Ratnapura - Northern Sinharaja; C3: Southern SinharajaHiniduma-Kanneliya; D: Foothills of Adam's Peak North of Ratnapura-Ambagamuwa; E: Kandy - upper Mahaweli; F: Knuckles; G: Central Mountains Ramboda - Nuwara Eliya; H: Adam's Peak; I: Horton Plains. at the level of species such as Angraecum zeylanicum (Orchidaceae), which is restricted to Sri Lanka and the Seychelles; Agrimonia pilosa (Rosaceae), the range of which, except for Sri Lanka, extends from Sikkim and Meghalaya to China and Japan (Chung 2008; Anon., 2013); and Cryptostylis arachnites (Orchidaceae), the range of which includes much of tropical and subtropical Asia, extending to the western Pacific islands, but excludes the peninsula of India. The reasons for the absence from Peninsular India of these species, and indeed the genera in Table 1, remain elusive. Still other species occur in Sri Lanka and only sparsely or rarely in southern Kerala, are absent from the Deccan Peninsula, but then recur farther afield. For example, Hypserpa nitida (Manispermaceae) occurs in the lower central hills of Sri Lanka, in Kerala, and then again only in Assam and eastwards to the Philippines; and Gyrinops walla (Thymelaeaceae) is restricted to Sri Lanka and Kerala, where it is rare; all other species in the genus are restricted to Southeast Asia. The question remains as to whether these taxa once populated the Deccan Peninsula and became extinct there, or whether they were shared with the Malay region by some other route, never entering peninsular India ${ }^{2}$.

2 Ashton (2014: 411-415) argues that the biotic isolation of the Indian peninsula may have been caused by "Chatterjee's " a physiographic barrier that extends from the Chin species distribution patterns," he wrote, "a exter first truly extraordinary that so many tree families apparently failed to cross the Gangetic Plain." 
Table 1: Genera of plants occurring in Sri Lanka and elsewhere other than the peninsula of India.

\begin{tabular}{|c|c|c|}
\hline Genus & Family & Distribution outside Sri Lanka \\
\hline Erythrospermum & Achariaceae & Mauritius, China, New Guinea, Samoa, Fiji (Dassanayake and Fosberg, 1980-2006) \\
\hline Ptyssiglottis & Acanthaceae & $\begin{array}{l}\text { Indochina, Sumatra, Java, Borneo, Philippines, New Guinea, Bismarck Archipelago } \\
\text { (Hansen, 1992) }\end{array}$ \\
\hline Campnosperma & Anacardiaceae & Malesia, tropical Africa, tropical America (Dassananayke and Fosberg, 1980-2006) \\
\hline Cleghornia & Apocynaceae & Peninsular Malaysia, China (Anon., 2013) \\
\hline Dischidia & Apocynaceae & $\begin{array}{l}\text { SE Asia, Malesia,E Himalayas to Taiwan, New Guinea, NE Australia (Dassananayke } \\
\text { and Fosberg, 1980-2006). }\end{array}$ \\
\hline Ochrosia & Apocynaceae & Indian Ocean to Pacific (Anon., 2013) \\
\hline Willughbeia & Apocynaceae & Assam to Philippines (Anon., 2013) \\
\hline Oncosperma & Arecaceae & Philippines (Anon., 2013) \\
\hline Rhipsalis & Cactaceae & Mascerenes, the Americas (Dassananayke and Fosberg, 1980-2006) \\
\hline Axinandra & Crypteroniaceae & Borneo and the Malay Peninsula (Rutschmann et al., 2004) \\
\hline Scirpodendron & Cyperaceae & NE India to W Pacific (Anon., 2013) \\
\hline Tricostularia & Cyperaceae & China to Australia (Anon., 2013) \\
\hline Adenochlaena & Euphorbiaceae & Comoros, Madagascar (Anon., 2013) \\
\hline Peltophorum & Fabaceae & Malaysia, N Australia (Dassananayke and Fosberg, 1980-2006; Haston et al., 2005) \\
\hline Strongylodon & Fabaceae & $\begin{array}{l}\text { Madagascar, Reunion, NE Australia, New Guinea, Sulawesi, Philippines, W Pacific } \\
\text { islands (Huang, 1991) }\end{array}$ \\
\hline Crawfurdia & Gentianaceae & $\begin{array}{l}\text { China, Vietnam, Burma, Bhutan, Sikkim, NE India (Dassananayke and Fosberg, } \\
\text { 1980-2006; Favre et al., 2010) }\end{array}$ \\
\hline Hanguana & Hanguanaceae & Malaysia to Micronesia (Anon., 2013) \\
\hline Glossocarya & Lamiaceae & Myanmar to Queensland (Anon., 2013) \\
\hline Dicellostyles & Malvaceae & Thailand (Phuphathanaphong, 1994) \\
\hline Hypserpa & Menispermaceae & Indo-Malesia, NE Australia, Caroline Is., New Caledonia, Vanuatu (Forman, 1997) \\
\hline Allaeanthus & Moraceae & Philippines, Sulawesi, Madagascar (Chung et al., 2017) \\
\hline Nepenthes & Nepenthaceae & $\begin{array}{l}\text { Indomalaya, Seychelles, Madagascar, Assam, Indochina, New Guinea, N Australia, } \\
\text { New Caledonia (Meimberg et al., 2001) }\end{array}$ \\
\hline Angraecum & Orchidaceae & Seychelles; tropical and S Africa (Anon., 2013) \\
\hline Bromheadia & Orchidaceae & Myanmar, Indochina, Indomalaya, Australia (Anon., 2013) \\
\hline Cryptostylis & Orchidaceae & Tropical and subtropical Asia, Australia, W Pacific islands (Anon., 2013) \\
\hline Erythrodes & Orchidaceae & $\begin{array}{l}\text { Assam to Philipppines; West Pacific Islands (Anon., 2013; Fernando and Ormerod, } \\
\text { 2008) }\end{array}$ \\
\hline Freycinetia & Pandanaceae & $\begin{array}{l}\text { China, Indochina, Indomalaya, Philippines, NE Australia, Pacific Islands, New } \\
\text { Zealand (Dassananayke and Fosberg, 1980-2006; Anon., 2013) }\end{array}$ \\
\hline Thuarea & Poaceae & Madagascar to Pacific (Anon., 2013) \\
\hline Dichilanthe & Rubiaceae & Borneo (Anon., 2013) \\
\hline Prismatomeris & Rubiaceae & $\begin{array}{l}\text { NE India to S China, W Indonesia, Philippines (Dassananayke and Fosberg, 1980- } \\
\text { 2006; Anon., 2013) }\end{array}$ \\
\hline Urophyllum & Rubiaceae & Malaysia to Philippines (Anon., 2013) \\
\hline Dovyalis & Salicaceae & Africa (Dassananayke and Fosberg, 1980-2006) \\
\hline Ginalloa & Santalaceae & SE Asia (Dassananayke and Fosberg, 1980-2006) \\
\hline Notothixos & Santalaceae & $\begin{array}{l}\text { Malay Peninsula, Indonesia, Australia (Dassananayke and Fosberg, 1980-2006; } \\
\text { Bussing, 2003) }\end{array}$ \\
\hline Osmelia & Salicaceae & Malay Peninsula to New Guinea (Dassananayke and Fosberg, 1980-2006) \\
\hline Gyrinops & Thymelaeaceae & Sunda Islands, Sulawesi, Molluccas, New Guinea (Eurlings and Gravendeel, 2005) \\
\hline Phaleria & Thymelaeaceae & Malesia, Micronesia, Samoan Islands, Tonga, Australia (Herber, 2001) \\
\hline Sciaphila & Triuridaceae & Japan, Solomon Islands (Anon., 2013) \\
\hline
\end{tabular}


Despite barely 25 years having elapsed since the publication of Darwin's revolutionary On the origin of species (1859), it is clear that Trimen had fully absorbed the implications of that work. For example, as seen from his comparison of the Nilgiri flora with that of the Ceylon hills, he concluded from the fact that nearly all the genera are shared, though about half the species are endemic to each region, that the two floras had been terrestrially connected relatively recently. Such a conclusion implies a postulation not only of much lower sea levels but also of a much cooler and less seasonal climate in the present-day 'dry-zone' of Sri Lanka's northern plains.

Trimen (1885) extended this inference to conclude that should only families be shared by two regions (and not genera or species), their connection must have been more ancient, and cited a telling example.

"The two richest and most specialized floras in the world, as already noticed, are those of the [African] Cape and Australia; probably scarcely a genus is common to them, yet the large and well-marked Natural Orders Proteaceae and [Restionaceae] are abundant in each of these far distant regions, and are almost confined entirely to them. This, according to the present views, implies a common focus of origin in a remote past." 3

Just as in the case of the Nilgiris and Ceylon Highlands, the mechanism by which Australia and Africa, now separated by $8,000 \mathrm{~km}$ of ocean, had once been connected was unknown to Trimen; but he showed that such a connection must once have existed.

\section{ZOOGEOGRAPHY}

Trimen's (1885) recognition of the close relationship between the floras of Ceylon on the one hand, and of the southern Western Ghats and Indomalaya on the other, had been anticipated by Alfred Russell Wallace (1823-1913) for the fauna just eight years earlier. In his "Geographical distribution of Animals", Wallace (1877) considered Sri Lanka, together with South India, as a distinct sub-region of his Oriental region, thereby recognizing the distinction of the biota of this sub-region from that of the rest of India. "The Island of Ceylon is characterized by such striking peculiarities in its animal productions," he noted, "as to render necessary its separation from the peninsula of India as a sub-region; but it is found that most of these special features extend to the Neilgherries and the whole southern mountainous portion of India, and that the two must be

\footnotetext{
3 Darwin too, nudged at the idea of a Gondwanan connection for which, however, there was as at that time no evidence. "America, and the other southern lands", he wrote (1859), "have been stocked in part from a nearly intermediate though distant point, namely from the antarctic islands, when they were clothed with vegetation, during a warmer tertiary period, before the commencement of the last Glacial period. The affinity... between the flora of the south-western corner of Australia and of the Cape of Good Hope, is a far more remarkable case: but this affinity is confined to the plants, and will, no doubt, some day be explained." Indeed, it has.
}

united in any zoo-geographical province. The main features of this division are, -the appearance of numerous animals allied to forms only found again in the Himalayas or in the Malayan sub-region, the possession of several peculiar generic types, and an unusual number of peculiar species."

While many of the relationships Wallace observed between Sri Lanka and Indomalaya were the result of taxonomic error, his observations with regard to the reptile fauna were remarkably prescient. "It is however by its reptiles, even more than by its higher vertebrates, that this sub-region is clearly characterized", he wrote. "Among snakes it possesses an entire family, Uropeltidae, consisting of 5 genera and 18 species altogether confined to it, and Uropeltis in Ceylon, Silybura, Plecturus and Melanophidium in Southern India. Four other genera of snakes, Haplocercus, Cercaspis, Peltopelor, and Hypnale are also peculiar; Chersydrus is only found elsewhere in Malaya; while Aspidura, Passerita, and Cynophis, only extend to Hindostan; and species of Eryx, Echis, and Psammophis show an affinity with Ethiopian and Paleearctic forms. Among lizards several genera of Agamidae are peculiar, such as Otocryptis, Lyricoephalus, Ceratophora, Cophotis, Salea, Sitana and Charasia. In the family Acontiadae, Nessia is peculiar to Ceylon, while a species of the African genus Acontias shows an affinity for the Ethiopian region."

Wallace (1877) postulated land connections between Sri Lanka and other regions to explain the animal distributions he observed. In order to explain the distribution of the lemurine primates, he posited an extensive southern continent or great island comprising of Sri Lanka and Southern India, formerly connected with Madagascar and Africa. And to explain the affinities between Malayan region on the one hand, and Sri Lanka and South India on the other, he suggested proximal land connections also between the two regions.

Among the few other noteworthy contributors to Sri Lankan zoogeography was E.W.H. Holdsworth (18291915), who first described the geographical distribution of bird species within the island, giving detailed locality information. Ripley (1949) added to this work, drawing particular attention to the close connection between the Sri Lankan and Malayan avifaunas. Ludwig Hermann Plate (1862-1937) in his four-volume Fauna et Anatomia ceylanica (1922-1931) provided detailed examinations of rarely-studied animals including caecilians, veronicellid slugs, leaf insects, chitons and reef fishes, covering a variety of fields including biogeography, while A. Humbert (1829-1887) was among the earliest workers who sought to explain the similarities of the insular faunas of the Sunda

4 The shieldtail-snake family Uropeltidae, and also the hump nosed pit vipers of the genus Hypnale, are largely restricted to Sri Lanka and southern India. The genus Cercaspis, though earlier considered endemic to Sri Lanka, has been shown in the molecular analysis of Pyron et al., (2013) to be a synonym of the more widespread genus Lycodon, with Haplocercus shown to be a synonym of the Sri Lankan endemic genus Aspisdura. Several genera of reptiles present in southern India are absent from Sri Lanka, including Chalcides, Draco, Ophiophagus, Rhabdops, Salea, Indotestudo, Scincella and Psammophis (Das, 1996). 
islands by positing ancient terrestrial connections, uplift and sea level fluctuations. D.N. Wadia (1883-1969) made important contributions to the formation of the Himalayas, the Western Ghats and the mountains of Sri Lanka. His work on identification of the plains of erosion in Sri Lanka facilitated important research on Sri Lankan biogeography and climate, laying the ground for the biogeographic characterisation of the island by future authors.

For the freshwater fishes, Hora $(1952 ; 1953)$ listed fifteen species in six families in peninsular India that are widely separated from other populations of the same species farther east, suggesting that these fishes invaded India not much before the Pliocene, too late for them to reach Sri Lanka. Hora postulated that they crossed into the peninsula of India via the Satpura and other hill ranges during a pluvial phase.

\section{CONCLUSION}

Sri Lanka's southwestern wet zone is the repository of the preponderant majority of its endemic taxa. While a quantitative characterization of the distribution of plants and animals within the island is now within reach as a result of the accumulation of a vast volume of geospatial data, such an analysis yet remains to be made. By the time of Independence in the mid-20th century, however, a stable picture of the external relationships of the island's biota had emerged: close and evidently recent links to the southern Western Ghats of India; older links to Indomalaya, evidently severed by the Gangetic Chatterjee Partition and the subsequent desiccation of much of the Indian peninsula; and a handful of possible 'Gondwanan' links to Madagascar. There is even now, however, insufficient data upon which to explain the large number of biotic disjunctions between Sri Lanka and regions further afield, though dispersal appears to be the most likely explanation for most of these.

\section{ACKNOWLEDGEMENTS}

We thank the three reviewers who commented on this manuscript and made some important corrections and clarifications.

\section{REFERENCES}

Anonymous, (2013). The Plant List. Version 1.1. Published on the Internet; http://www.theplantlist.org/

Ashton, P. 2014. On the forests of tropical Asia: lest the memory fade. Royal Botanic Gardens, Kew. 670 pp.

Ashton, P. S., and Gunatilleke, C. V. S. (1987). New light on the plant geography of Ceylon. I. Historical plant geography. Journal of Biogeography 14: 249-285.

Ashton, M. S., Gunatilleke, S., De Zoysa, N., Dassanayake, M. D., Gunatilleke, N., and Wijesundera, S. (1997). A field guide to the common trees and shrubs of Sri Lanka. Colombo, Sri Lanka: WHT Publications.

Bussing, A. (2003). Mistletoe: the genus Viscum. CRC Press.

Chung, K. S. (2008). A systematic study of genus Agrimonia (Rosaceae). Ph.D. dissertation. The University of
Oklahoma.

Chung, K. F., Kuo, W. H., Hsu, Y. H., Li, Y. H., Rubite, R. R., and Xu, W. B. (2017). Molecular recircumscription of Broussonetia (Moraceae) and the identity and taxonomic status of $B$. kaempferi var. australis. Botanical Studies 58: 11.

Darwin, C. 1861. On the origin of species by means of natural selection, or the preservation of favoured races in the struggle for life. London: Murray. $3 \mathrm{~d}$ ed.

Das, I. 1996. Biogeography of the reptiles of South Asia. Krieger Publishing Co., Malabar, Floridar. 87 pp.

De Rosayro, R. A. (1950). Ecological conceptions and vegetational types with special reference to Ceylon. Tropical Agriculturist 106: 108-121.

De Vries, H. (1916). The origin by mutation of the endemic plants of Ceylon. Science 43: 785-787.

Dassanayake, M.D. and Fosberg, F.R. (Ed.) (1980-2006). $A$ revised handbook to the flora of Ceylon, 16 vols. Oxford and IBH Publishing Co. New Delhi.

Dutta, S. K., and Manamendra-Arachchi, K. (1996). The amphibian fauna of Sri Lanka. Wildlife Heritage Trust of Sri Lanka.

Eurlings, M. C. M., and Gravendeel, B. (2005). TrnLtrnF sequence data imply paraphyly of Aquilaria and Gyrinops (Thymelaeaceae) and provide new perspectives for agarwood identification. Plant systematics and evolution 254: 1-12.

Favre, A., Yuan, Y. M., Küpfer, P., and Alvarez, N. (2010). Phylogeny of subtribe Gentianinae (Gentianaceae): biogeographic inferences despite limitations in temporal calibration points. Taxon 59: 1701-1711.

Fernando, S. S., and Ormerod, P. (2008). An annotated checklist of the orchids of Sri Lanka. Rheedea 18: 1-28.

Forman, L. L. (1997). A synopsis of Hypserpa Miers (Menispermaceae). Kew Bulletin 52: 981-987.

Gaussen, H., Legris, P., Viart, M., and Labroue, L. (1966). International map of the vegetation: Ceylon. Ceylon Survey Department.

Green, M. J. B. (1995). Preliminary analysis of biodiversity within Sri Lanka's wet zone forests. Colombo: Forest Department/ UNDP/FAO/IUCN.

Greller, A. M. and Balasubramanium, S. (1993). Physiognomic, floristic and bioclimatological characterisation of the major forest types of Sri Lanka. In: Erdelen, W., C. Preu, N. Ishwaran and C. Madduma Bandara (eds.), Ecology and Landscape Management in Sri Lanka: Proceedings of the International and Interdisciplinary Symposium. Margraf Verlag, Weikersheim, Germany. Pp. 55-78.

Grove, R. (1998). Indigenous knowledge and the significance of South-West India for Portuguese and Dutch constructions of tropical nature. In: Grove, R.H., V., Damodaran and Sangwan (eds), Nature and the orient: The environmental history of South and southeast Asia, Delhi: Oxford University Press. Pp. 187-209.

Gunatilleke, S., Gunatilleke, N., and Pethiyagoda, R. (2008). Biodiversity of Sri Lanka. Journal of National Science Foundation of Sri Lanka 36: 25-62.

Hansen, B. (1992). The genus Ptyssiglottis (Acanthaceae). 
A taxonomic monograph. Opera Botanica 116: 1-58.

Haston, E. M., Lewis, G. P., and Hawkins, J. A. (2005). A phylogenetic reappraisal of the Peltophorum group (Caesalpinieae: Leguminosae) based on the chloroplast trnL-F, rbcL and rps16 sequence data. American Journal of Botany 92: 1359-1371.

Heniger, J. (1986). Hendrik Adriaan Van Reed Tot Drakestein (1636-1691) and Hortus, Malabaricus: A Contribution to the History of Colonial Botany. Balkema, Rotterdam.

Herber, B. E. (2001). Oreodendron CT White reduced to Phaleria Jack (Thymelaeaceae, Thymelaeoideae). Austrobaileya 6: 95-97.

Hora, S. L. (1952). Recent advances in fish geography of India. Journal of Bombay Natural History Society 51: 170-188.

Hora, S. L. (1953). The Satpura hypothesis. Science Progress 41: 245-255.

Huang, S. F. (1991). Strongylodon (LeguminosaeErythrininae), a revision of the genus (No. 90-8, p. 69). Wageningen: Agricultural University.

Koelmeyer, K. O. (1957). Climatic classification and distribution of vegetation in Ceylon. The Ceylon Forester 3: 144-163.

Linnaeus, C. (1758). Systema Naturae, Vol. 1. Engelman, Leipzig.

Lourteig, A. (1966). L'herbier de Paul Hermann, base du Thesaurus zeylanicus de Johan Burman. Taxon 15: 2333.

Lyell, C. (1853). Principles of Geology: or The Modern Changes of the Earth and its Inhabitants (9th ed.). Appleton and Company, New York.

Manamendra-Arachchi, K., and Liyanage, S. (1994). Conservation and distribution of the agamid lizards of Sri Lanka with illustrations of the extant species. Journal of South Asian Natural History 1: 77-96.

Manamendra-Arachchi, K., and Pethiyagoda, R. (2005). The Sri Lankan shrub-frogs of the genus Philautus Gistel, 1848 (Ranidae: Rhacophorinae), with description of 27 new species. Raffles Bulletin of Zoology 12: 163-303.

Manthey, U., and Grossmann, W. (1997). Amphibien and Reptilien Südostasiens. Natur-und-Tier-Verlag.

Meimberg, H., Wistuba, A., Dittrich, P., and Heubl, G. (2001). Molecular phylogeny of Nepenthaceae based on cladistic analysis of plastid trnK intron sequence data. Plant Biology 3: 164-175.

Peiris, E. (1952). Paul Hermann, the father of Ceylon botany. Journal of the Ceylon Branch of the Royal Asiatic Society 2: 1-20.

Pennant, T. (1777). British Zoology. 4th ed. Warrington.

Pennant, T. (1781a). Genera of birds. 2nd ed. London.

Pennant, T. (1781b). History of Quadrupeds. London.

Pethiyagoda, R. (2007). Pearls, Spices, and Green Gold: An Illustrated History of Biodiversity Exploration in Sri Lanka. WHT Publications.

Phuphathanaphong, L. (1994). Dicellostyles, A genus of Malvaceae newly recorded for Thailand. Thai Forest Bulletin (Botany) 21: 124-126.

Pyron, R. A., Kandambi, H. D., Hendry, C. R., Pushpamal, V., Burbrink, F. T., and Somaweera, R. (2013). Genus- level phylogeny of snakes reveals the origins of species richness in Sri Lanka. Molecular Phylogenetics and Evolution 66: 969-978.

Rauschert, S. (1970). Das Herbarium von Paul Hermann (1646-1695) in der Forschungbibliothek Gotha. Hercynia N.F. 7: 301-328.

Rice, A. L. (1999). Voyages of Discovery: three centuries of natural history exploration. The Natural History Museum, London.

Ridley, H. N. 1916. Endemism and the mutation theory. Annals of Botany 30:551-574.

Ripley, S. D. 1949. Avian relicts and double invasions in peninsular India and Ceylon. Evolution 3: 150-159.

Rutschmann, F., Eriksson, T., Schönenberger, J., and Conti, E. (2004). Did Crypteroniaceae really disperse out of India? molecular dating evidence from rbc L, ndh F, and rpl 16 intron sequences. International Journal of Plant Sciences 165: S69-S83.

Shaw, T. (1972). Early agriculture in Africa. Journal of the Historical Society of Nigeria 6: 143-192.

Sinnott, E. W. and Bailey, I. W. (1914). Investigations on the phylogeny of the angiosperms: No. 4. The origin and dispersal of herbaceous angiosperms. Annals of Botany 28: 547-600.

Trimen, H. (1885). Remarks on the composition, geographical affinities, and origin of the Ceylon flora. Journal of the Royal Asiatic Society, Ceylon Branch 9: $1-21$.

Trimen, H. (1886). On the flora of Ceylon, especially as affected by climate. Journal of Botany 24: 801-805.

Trimen, H. (1887). Hermann's Ceylon Herbarium and Linnæus's 'Flora Zeylanica'. Journal of the Linnean Society of London, Botany 24: 129-155.

van Ooststroom, S. J. (1937). Hermann's collection of Ceylon plants in the Rijksherbarium (National herbarium) at Leyden. Blumea. Supplement 1: 193-209.

Vaughan, J. G., and Geissler, C. (1997). The new Oxford book offood plants. New York: Oxford University Press

Wallace, A. R. (1876). The geographical distribution of animals, with a study of the relations of living and extinct faunas as elucidating the past changes of the earth's surface. Harper and Brothers, New York.

Wikramanayake, E. D. (2002). Terrestrial ecoregions of the Indo-Pacific: a conservation assessment. Island Press.

Willis, J. C. (1906). The flora of Ritigala, an isolated mountain in the North-Central Province of Ceylon; a study in endemism. Annual Report of the Botanic Gardens, Peradeniya 2: 271-302.

Willis, J. C. (1907). Some evidence against the theory of Natural Selection. Annual Report of the Botanic Gardens, Peradeniya 4: 17.

Willis, J. C. (1908). The floras of Hill tops in Ceylon. Annual Report of the Botanic Gardens, Peradeniya 4: 131-138.

Willis, J. C. (1911). The flora of Naminakuli-kanda, a somewhat isolated mountain in the province of Uva. Annual Report of the Botanic Gardens, Peradeniya 5: 217.

Willis, J. C. (1915). The endemic flora of Ceylon, with reference to geographical distribution and evolution 
in general. Philosophical Transactions of the Royal Society of London Series B 206: 307-342.

Willis, J. C. (1922). Age and area: a study in geographic distribution and origin of species. The University Press; Cambridge.

Willis, J. C. (1942). Evolution in plants by kaleidoscopic mutation. Philosophical Transactions of the Royal Society of London Series B 131: 161-169.
Willis, J. C. (1949). The birth and spread of plants. Conservatoire Et Jardin Botaniques La Ville; Switzerland. 